University of Nebraska - Lincoln

DigitalCommons@University of Nebraska - Lincoln

\title{
Latin Hypercube Approach to Estimate Uncertainty in Ground Water Vulnerability
}

Jason J. Gurdak

U.S. Geological Survey, jjgurdak@usgs.gov

John E. McCray

Colorado School of Mines, jmccray@mines.edu

Geoffrey Thyne

Colorado School of Mines

Sharon L. Qi

U.S. Geological Survey, slqi@usgs.gov

Follow this and additional works at: https://digitalcommons.unl.edu/usgsstaffpub

Gurdak, Jason J.; McCray, John E.; Thyne, Geoffrey; and Qi, Sharon L., "Latin Hypercube Approach to Estimate Uncertainty in Ground Water Vulnerability" (2007). USGS Staff -- Published Research. 602. https://digitalcommons.unl.edu/usgsstaffpub/602

This Article is brought to you for free and open access by the US Geological Survey at DigitalCommons@University of Nebraska - Lincoln. It has been accepted for inclusion in USGS Staff -- Published Research by an authorized administrator of DigitalCommons@University of Nebraska - Lincoln. 


\title{
Latin Hypercube Approach to Estimate Uncertainty in Ground Water Vulnerability
}

\author{
by Jason J. Gurdak ${ }^{1,2}$, John E. McCray ${ }^{3}$, Geoffrey Thyne ${ }^{4}$, and Sharon L. $0 i^{5}$
}

\begin{abstract}
A methodology is proposed to quantify prediction uncertainty associated with ground water vulnerability models that were developed through an approach that coupled multivariate logistic regression with a geographic information system (GIS). This method uses Latin hypercube sampling (LHS) to illustrate the propagation of input error and estimate uncertainty associated with the logistic regression predictions of ground water vulnerability. Central to the proposed method is the assumption that prediction uncertainty in ground water vulnerability models is a function of input error propagation from uncertainty in the estimated logistic regression model coefficients (model error) and the values of explanatory variables represented in the GIS (data error). Input probability distributions that represent both model and data error sources of uncertainty were simultaneously sampled using a Latin hypercube approach with logistic regression calculations of probability of elevated nonpoint source contaminants in ground water. The resulting probability distribution represents the prediction intervals and associated uncertainty of the ground water vulnerability predictions. The method is illustrated through a ground water vulnerability assessment of the High Plains regional aquifer. Results of the LHS simulations reveal significant prediction uncertainties that vary spatially across the regional aquifer. Additionally, the proposed method enables a spatial deconstruction of the prediction uncertainty that can lead to improved prediction of ground water vulnerability.
\end{abstract}

\section{Introduction}

Interest in predicting nonpoint source (NPS) contamination in ground water has increased because of widespread detection of such contaminants and the implications for human and aquatic health and resource

${ }^{1}$ Corresponding author: U.S. Geological Survey, Colorado Water Science Center, Denver Federal Center, Mail Stop 415, Lakewood, CO 80225; (303) 236-4882; fax (303) 236-4912; jjgurdak@ usgs.gov

2Department of Geology and Geological Engineering, Colorado School of Mines, 1516 Illinois St., Golden, CO 80401.

${ }^{3}$ Environmental Science and Engineering Division, Hydorologic Science and Engineering Program, Colorado School of Mines, 1500 Illinois St., Golden, CO 80401.

${ }^{4}$ Department of Geology and Geological Engineering, Hydrologic Science and Engineering Program, Colorado School of Mines, 1516 Illinois St., Golden, CO 80401.

5 U.S. Geological Survey, Cascades Volcano Observatory, 1300 S.E. Cardinal Court, Building 10, Suite 100, Vancouver, WA 98683; slqi@usgs.gov

Received May 2006, accepted November 2006.

Copyright (c) No claim to original US government works. Journal compilation (C) 2007 National Ground Water Association. doi: 10.1111/j.1745-6584.2006.00298.x sustainability. NPS ground water contamination poses, potentially, an even greater environmental concern than those from point sources because of the associated environmental implications of scale and variability (both spatial and temporal) of an areally diffuse (NPS) contaminant (Loague et al. 1996). Because ground water remediation is expensive, slow, and often infeasible across moderate- to large-scale aquifers, successful environmental management toward prevention of NPS ground water contamination must identify and control contributing human activities and delineate susceptible regions of the aquifer.

In response to NPS ground water contamination, studies of ground water vulnerability have been abundant in the literature during recent years. Although individual approaches differ, ground water vulnerability assessments often have the same fundamental goals of estimating the potential for NPS ground water contamination, or areally distributed point sources of pollution, and providing scientifically defensible information to assist water resource managers during decisions regarding ground water remediation, protection, or sustainable management.

Most assessments conceptualize two distinct components to ground water vulnerability (Focazio et al. 2002): 
(1) intrinsic susceptibility, which defines the inherent aquifer properties (e.g., hydraulic conductivity, porosity, depth to water, soil type) of the ground water system and the associated sources of water and stresses of the system (i.e., rates and sources of recharge and discharge) and (2) specific vulnerability, or simply vulnerability, which considers the proximity of contaminant sources, fate and transport properties of the contaminant, and other factors that define potential loads of specified contaminants to the aquifer. The magnitude and variability of both components typically are approximated using best available interpolation or extrapolation methods.

Approaches to ground water vulnerability assessment can be classified as (1) index methods, which are often subjective and biased because of predetermined controlling factors included in the index; (2) process-based methods consisting of mathematical modeling to approximate contaminant fate and transport; and (3) empirically based statistical methods that correlate ground water chemistry and explanatory variables of the study area (Zhang et al. 1996). One useful statistical approach employs logistic regression.

Logistic regression modeling has been used extensively by epidemiologists (Magder and Hughes 1997) to estimate the effect of various predictors on some binary outcome of medical interest, but the approach has become more commonplace in environmental applications (Nolan et al. 2002), particularly for assessment of ground water vulnerability (Gurdak and McCray 2004). Logistic regression-based ground water vulnerability models have been demonstrated successfully across a range of systems, from subregional (Rupert 1998) to national scale (Nolan 2001; Nolan et al. 2002), and for a number of NPS contaminants. Eckhardt and Stackelberg (1995) developed logistic regression models to characterize the probability of NPS ground water contamination from volatile organic compounds, pesticides, and inorganic constituents. Squillace and Moran (2000) used logistic regression to estimate the likelihood of methyl tert-butyl ether occurrence in ground water of the Northeast and Mid-Atlantic regions of the United States. Although logistic regression has been widely used to predict ground water vulnerability to pesticides (Teso et al. 1996; Rupert 2003), nitrate is the most common NPS contaminant evaluated using logistic regression (Tesoriero and Voss 1997; Gurdak and Qi 2006). Twarakavi and Kaluarachchi (2005) used ordinal logistic regression, which differs from (binary) logistic regression in that multiple thresholds were considered while estimating probabilities of exceedance, to predict the probability of heavy metal occurrence in ground water. Additionally, output from logistic regression models can be displayed within a geographic information system (GIS) when the explanatory variables within the model are represented in geospatial databases. Thus, the coupling of logistic regression and GIS provides the means to spatially represent the risk of NPS ground water contamination, often as vulnerability maps.

Uncertainty is inherent to predictions of ground water vulnerability (Loague 1991; Loague et al. 1996), yet few ground water vulnerability assessments have accounted for, or reported, associated uncertainty. Coupling logistic regression modeling with a GIS extrapolation technique to predict ground water vulnerability has been a popular empirical methodology (Murray and McCray 2005); however, to the knowledge of the authors, no prior assessments using this approach have quantified uncertainty of spatial vulnerability predictions. A significant benefit of logistic regression analysis is that predictions of vulnerability are expressed in probabilistic terms. However, all uncertainty is not inherently represented within the resulting probabilistic predictions because unavoidable model and data errors propagate through logistic regression calculations, making predictions of vulnerability best estimates. Error propagation and resulting uncertainty of ground water vulnerability model predictions bear societal consequences. Consider, for example, hypothetical questions posed during site location of a proposed municipal well: "Does the quality of the ground water meet drinking water standards?"; "Are land-use activities impairing ground water quality?"; "How vulnerable is the ground water to NPS contamination?". A ground water vulnerability assessment can help answer such questions but with limited confidence if associated prediction uncertainty is significant. If results of ground water vulnerability assessments are to carry any weight in resource decision making, the associated predictive uncertainty needs to be quantified.

The work presented here was part of a larger study of ground water quality of the High Plains regional aquifer (Dennehy 2000). This portion of the study presents a novel method to estimate uncertainty associated with predictions of ground water vulnerability. Although the method was developed and tested in the High Plains regional aquifer, the analysis presented here can be applied to other aquifers where NPS contamination is of concern and logistic regression-based vulnerability assessments using spatially distributed explanatory variables as input are warranted. The method uses a stochastic approach for uncertainty estimation; Latin hypercube sampling (LHS) technique (McKay et al. 1979) was used to estimate selected prediction intervals for the vulnerability model output. The fundamental assumption of this method is that uncertainty in logistic regression predictions is a function of uncertainty in both the explanatory variables and regression coefficients, which can be expressed as probability distribution functions within the framework of logistic regression analysis of ground water vulnerability.

The objectives of this article were to (1) identify error propagation through coupled logistic regression and GIS vulnerability models; (2) develop and test a flexible methodology to estimate uncertainty due to input error propagation; and (3) demonstrate the methodology using actual data from a recent assessment of ground water vulnerability of the High Plains aquifer to elevated nitrate (more than $4 \mathrm{mg} / \mathrm{L}$ ) in recently recharged (less than 50 years) ground water, which is detailed by Gurdak and Qi (2006). This article describes the use of LHS in uncertainty analysis as a simple yet powerful approach and demonstrates its use in logistic regression GIS coupled ground water vulnerability models. 


\section{Theory}

\section{Logistic Regression Modeling}

Logistic regression analysis predicts the probability of a binary or categorical response based on independent or explanatory variables. Hosmer and Lemeshow (2000) and Menard (2002) present thorough reviews of logistic regression theory. Often, the objective of a ground water vulnerability assessment is to predict the occurrence of a water quality constituent above a certain level or threshold. Therefore, logistic regression is well suited for analysis of ground water vulnerability assessment because the binary response, or categorical response in the case of ordinal logistic regression (Twarakavi and Kaluarachchi 2005), can be established using a threshold that represents a drinking water standard, laboratory detection level, or relative background concentration. The underlying assumption of logistic regression is that the natural logarithm of the odds ratio is linearly related to the explanatory variables. The odd ratio (Equation 1) is based on the probability of being in a response category:

$$
\text { Odds ratio }=\frac{P}{1-P}
$$

where $P$ is the probability of exceeding the selected binary threshold value (Helsel and Hirsch 1992). The log of the odds ratio, or logit, transforms a binary response into a continuous variable that is a linear function of the explanatory variables (Helsel and Hirsch 1992). The logit transformation is as follows:

$$
\ln \left(\frac{P}{1-P}\right)=b_{\mathrm{o}}+b x
$$

where $b_{\mathrm{o}}$ is the logistic regression constant, $x$ is a vector of $k$ explanatory variable(s), and $b$ is a vector of slope coefficients for the explanatory variables. Predicted values of the response variable are converted back into probability units by using the logistic transformation, with the logistic regression model taking the form of:

$$
P=\frac{\mathrm{e}^{\left(b_{0}+b x\right)}}{1+\mathrm{e}^{\left(b_{0}+b x\right)}}
$$

where $P$ is the probability of the binary response event given $x$, defined here as the probability of detecting nitrate (as nitrogen) in ground water at a concentration greater than or equal to $4 \mathrm{mg} / \mathrm{L}$, and e is the base of natural logarithm.

A number of statistical parameters are calculated using logistic regression. These parameters aid the modeler in deciding how well the overall model works, how important each of the explanatory variables are in the overall model, and if the form of the model appears to be correct (Menard 2002). The log-likelihood ratio (LLR), commonly called $G$ statistic, measures the success and statistical significance of the logistic regression model as a whole by comparing observed with predicted values (Hosmer and Lemeshow 2000). The highest LLR indicates the most significant model, taking into account the degrees of freedom (number of explanatory variable) in the model. The $p$ values of the LLR indicate model significance of the model coefficients (null hypothesis is that slope $=0$ ). Specifically, $\alpha$ of 0.05 indicates a significance level of $5 \% ; \alpha$ of 0.01 indicates a significance level of $1 \%$. Logistic regression model-fitting criteria include the partial likelihood ratio, percent correct (PC) responses, and model sensitivity (Hosmer and Lemeshow 2000). The partial likelihood ratio is similar to the LLR but is evaluated to determine the significance of adding one or more new variables to an existing multivariate logistic regression model (Helsel and Hirsch 1992). A model with the addition of one new variable is more significant than the original model if the partial likelihood ratio is greater than the value of the chi-square distribution with degrees of freedom equal to one. The partial likelihood ratio was used exclusively during the iterative processes of the multivariate logistic regression analysis to select the explanatory variables that produce the best fitting model. Because of the large number of iterations, partial likelihood ratios and corresponding preliminary multivariate models are not listed in this article. The overall rate of correct classification, or PC responses, is the number of observed exceedances predicted by the model as exceedances, plus the number of observed nonexceedances predicted as nonexceedances, divided by the combined number of observed exceedances and nonexceedances (Hosmer and Lemeshow 2000). Sensitivity is defined as the number of observed exceedances predicted as exceedances divided by the total number of observed exceedances. Higher values of PC and sensitivity indicate better fitting models.

\section{Estimation of Uncertainty and LHS}

Uncertainty addresses the reliability surrounding the prediction of ground water vulnerability and can be broadly classified as related to either data or model error. Ground water vulnerability predictions are estimates that approximate the true risk of elevated NPS contamination. Vulnerability estimates have inherent prediction error, defined as the difference between the true and estimated risk of vulnerability. The magnitude of the prediction error is uncertain because the true risk is never known exactly.

Prediction error, or uncertainty, is a function of data error from GIS-based explanatory variables (expressed as $x$ in Equation 3) and model error of estimated logistic regression coefficients (expressed as $b_{\mathrm{o}}$ and $b$ in Equation 3). Within a GIS database, explanatory variables are imperfect representations of the real world because of unavoidable errors in accuracy, which refers to the closeness of represented measurements or computations to their "true" value, and precision, which refers to the number of digits used to report the measurement (Gottsegen et al. 1999). Therefore, GIS-based explanatory variables inherently introduce data error into logistic regression models. In addition, logistic regression coefficients are subject to estimation error (van Horssen et al. 2002). Both sources of error propagate through the logistic regression model to produce a combined uncertainty in the model output, which is typically expressed as a ground water vulnerability map. 
A stochastic modeling approach is presented to illustrate the propagation of input error and to estimate uncertainty associated with output of the logistic regressionbased vulnerability models that are coupled with GIS data. LHS is a widely used variation on the standard Monte Carlo (MC) stochastic sampling method for performing uncertainty analysis. The MC technique uses simple random sampling of the input probability distributions and commonly requires a large number of realizations to approximate the input probability distribution. In contrast, LHS uses a stratified sampling technique that allows distribution of samples drawn to correspond more closely with the input probability distribution. For the same number of samples, the LHS correspondence produces an unbiased estimate of the mean and a smaller variance, as compared to MC. This smaller variance translates in a greater confidence, fewer model simulations, and faster computation times. This is especially beneficial for complex model simulations because running enough simulations to properly represent the input distribution may be impractical using MC.

\section{Site Description}

The High Plains regional aquifer underlies an area of about $450,700 \mathrm{~km}^{2}$ in parts of eight western states (Figure 1) and can be subdivided into the Northern High Plains (NHP), Central High Plains (CHP), and Southern

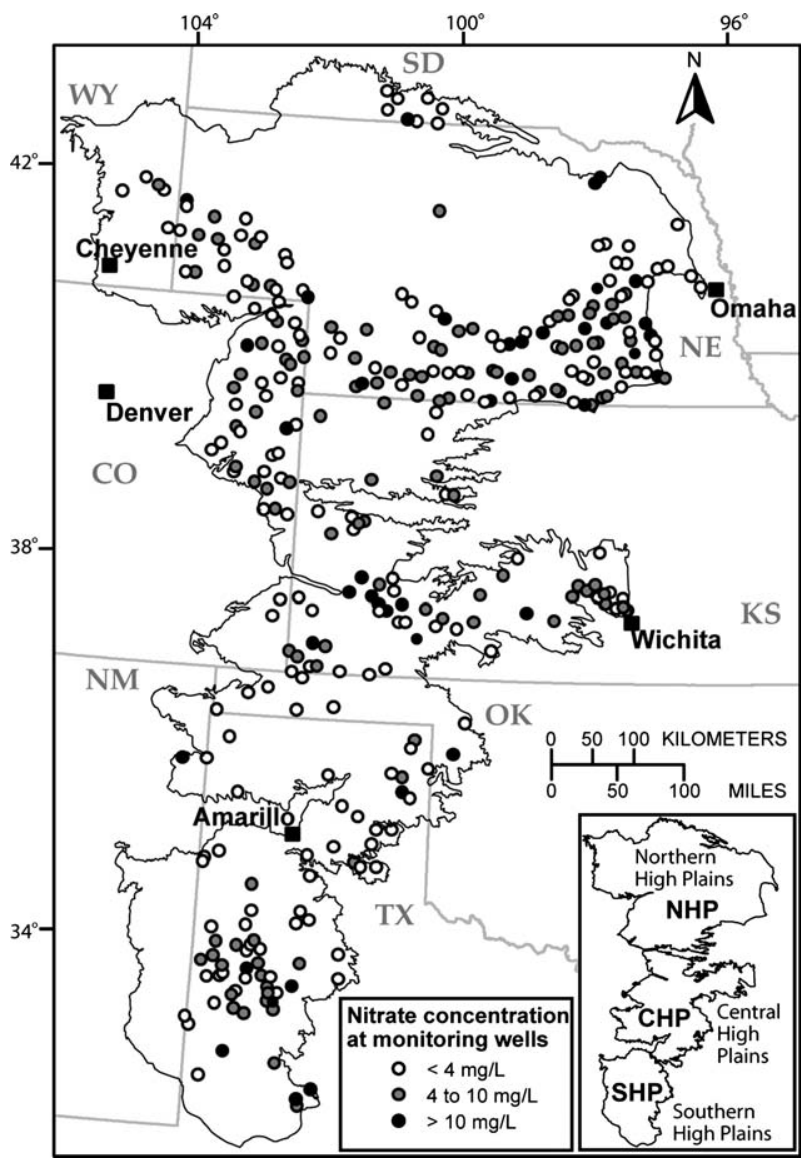

Figure 1. Map showing the location of the High Plains aquifer, location of monitoring wells, and associated nitrate concentrations.
High Plains (SHP) aquifers. The predominant ground water use of the aquifer supports a substantial agricultural industry. The High Plains aquifer encompasses approximately $27 \%$ of the nation's irrigated agricultural land and yields $30 \%$ of the ground water used for irrigation in the United States (Dennehy 2000).

The High Plains aquifer is generally unconfined. The Ogallala Formation is the principal hydrogeologic unit and underlies approximately $347,060 \mathrm{~km}^{2}$ (Luckey et al. 1986). This formation consists primarily of unconsolidated clay, silt, sand, and gravel. Local and sometimes extensive clay layers are present within the unsaturated sediments and below the water table. In 2000, the depth to water ranged from less than 3 to greater than $90 \mathrm{~m}$ below land surface, and saturated thickness ranged from less than 1 to greater than $365 \mathrm{~m}$ (Gurdak and Qi 2006). Recharge occurs by infiltration of irrigation water, precipitation, storm water runoff through streambeds and other topographic depressions, and upward movement of water from underlying aquifers (McMahon 2001).

Similar to other aquifers beneath agricultural regions, the ground water in the High Plains aquifer is vulnerable to nitrate contamination. Nitrate concentrations above background concentrations in ground water of the High Plains aquifer have been documented by a number of recent studies of ground water quality (McMahon et al. 2006; Bruce et al. 2003). Based on nitrate concentrations in paleorecharged ground water of the High Plains aquifer (McMahon et al. 2004), Gurdak and Qi (2006) estimated the background nitrate concentration in recently recharged ground water (less than 50 years) as less than or equal to $4 \mathrm{mg} / \mathrm{L}$ (as $\mathrm{N}$ ) and reported concentrations ranging from 0.02 to $31 \mathrm{mg} / \mathrm{L}$ (median, $3.82 \mathrm{mg} / \mathrm{L}$ ). Approximately $48.2 \%$ (162 of 336) of these samples of recently recharged ground water contain nitrate concentrations that exceed $4 \mathrm{mg} / \mathrm{L}$, and approximately $12.7 \%$ (43 of 336) of the samples have nitrate concentrations that exceed the U.S. EPA established Maximum Contaminant Level for nitrate in public drinking water of $10 \mathrm{mg} / \mathrm{L}$ (as N) (U.S. EPA 2004). The spatial distribution of nitrate in the High Plains aquifer is complex and poorly understood. Generally, nitrate concentrations in ground water vary spatially, and human activity during the past 50 years has resulted in nitrate concentrations in recently recharged water that are significantly larger than concentrations in older water in the aquifer (McMahon et al. 2004; Gurdak and Qi 2006).

\section{Methods}

The methods for ground water vulnerability model and map development using logistic regression coupled with GIS are explained in detail by Gurdak and Qi (2006) and Qi and Gurdak (2006) and are summarized as follows. Ground water flow and particle-tracking simulations using Visual MODFLOW 2.8 (Waterloo Hydrogeologic 1999) defined saturated zone depth criteria during selection of wells that intercept recently (less than 50 years) recharged ground water and delineated the shape of the contributing area for each well. All published ground water quality data and GIS-based hydrogeologic and 
anthropogenic explanatory variables (Gurdak and Qi 2006) were compiled for these wells $(n=336)$ (Table 1). Using a GIS and previously defined contributing areas, explanatory data (Table 1) were extracted for each well.
These data were analyzed using SAS 8.02 (SAS Institute 1999) statistical software. Through a stepwise model calibration approach using univariate and multivariate logistic regression analysis (Hosmer and Lemeshow 2000),

\begin{tabular}{|c|c|c|c|}
\hline \multicolumn{4}{|c|}{$\begin{array}{c}\text { Table } 1 \\
\text { Univariate Logistic Regression Analysis Results, Listing Logistic Regression Coefficients, and } p \text { Values }\end{array}$} \\
\hline & & $\begin{array}{l}\text { NHP Model } \\
\text { Coefficient }(p \text { value })\end{array}$ & $\begin{array}{l}\text { CHP and SHP Model } \\
\text { Coefficient ( } p \text { value) }\end{array}$ \\
\hline \multicolumn{4}{|c|}{ Explanatory Variable } \\
\hline Irrag & Irrigated agricultural land in sector $(\%)^{1}$ & $0.007(0.200)$ & $0.001(0.859)$ \\
\hline NonIrrag & Nonirrigated agricultural land in sector $(\%)^{1}$ & $0.012(0.025)$ & $0.010(0.065)$ \\
\hline Agland & $\begin{array}{l}\text { Irrigated and nonirrigated } \\
\quad \text { agricultural land in sector }(\%)^{1}\end{array}$ & $0.016(0.002)$ & $0.010(0.069)$ \\
\hline Nfert & $\begin{array}{l}\text { County-based expenditures on } \\
\text { commercial fertilizer (kg/county })^{2}\end{array}$ & $-2.55 \times 10^{-8}(0.425)$ & $5.10 \times 10^{-8}(0.125)$ \\
\hline Nmanr & $\begin{array}{l}\text { County-based expenditures on } \\
\text { manure }(\mathrm{kg} / \text { county })^{2}\end{array}$ & $-1.12 \times 10^{-7}(0.086)$ & $-6.27 \times 10^{-8}(0.170)$ \\
\hline Nfarmfert & $\begin{array}{l}\text { County-based expenditures on } \\
\text { fertilizer for agriculture }(\mathrm{kg} / \text { county })^{3}\end{array}$ & $-2.43 \times 10^{-8}(0.465)$ & $5.38 \times 10^{-8}(0.121)$ \\
\hline Nnonffert & $\begin{array}{l}\text { County-based expenditures on fertilizer } \\
\text { for nonagriculture }(\mathrm{kg} / \text { county })^{3}\end{array}$ & $-3.00 \times 10^{-5}(0.122)$ & $5.06 \times 10^{-7}(0.674)$ \\
\hline ManCon & $\begin{array}{l}\text { County-based expenditures on manure } \\
\text { from confined animals ( } \mathrm{kg} / \text { county })^{3}\end{array}$ & $-6.22 \times 10^{-8}(0.482)$ & $-7.07 \times 10^{-8}(0.215)$ \\
\hline ManUncon & $\begin{array}{l}\text { County-based expenditures on manure } \\
\text { from unconfined animals ( } \mathrm{kg} / \text { county })^{3}\end{array}$ & $-4.87 \times 10^{-7}(0.004)$ & $-2.78 \times 10^{-7}(0.119)$ \\
\hline Atmdep & $\begin{array}{l}\text { Estimated atmospheric deposition } \\
\text { of nitrogen }(\mathrm{kg} / \text { county })^{3}\end{array}$ & $-7.00 \times 10^{-5}(0.026)$ & $-7.00 \times 10^{-5}(0.100)$ \\
\hline Nresfert & $\begin{array}{l}\text { Estimated residual nitrogen in soil from } \\
\text { commercial fertilizer (kg of N/acre })^{2}\end{array}$ & $0.011(0.616)$ & $-0.009(0.749)$ \\
\hline Nresmanr & $\begin{array}{l}\text { Estimated residual nitrogen in soil } \\
\text { from manure }(\mathrm{kg} \text { of } \mathrm{N} / \mathrm{acre})^{2}\end{array}$ & $0.010(0.650)$ & $-0.016(0.121)$ \\
\hline Irrwells & Number of irrigation wells in sector ${ }^{2}$ & $-0.017(0.699)$ & $0.089(0.548)$ \\
\hline Withdrw & $\begin{array}{l}\text { Water withdrawal adjusted for irrigated land } \\
\text { (gal/d/acre of irrigated land })^{6}\end{array}$ & $2.64 \times 10^{-4}(0.170)$ & $-1.70 \times 10^{-4}(0.363)$ \\
\hline \multicolumn{4}{|l|}{ Hydrogeology } \\
\hline Precip & Average annual precipitation $(\mathrm{cm})^{5}$ & $0.046(0.251)$ & $0.029(0.549)$ \\
\hline Thick & Soil thickness $(\mathrm{m})^{6}$ & $0.064(0.457)$ & $0.005(0.851)$ \\
\hline Perm & Soil permeability $(\mathrm{cm} / \mathrm{h})^{6}$ & $-0.078(0.131)$ & $0.016(0.824)$ \\
\hline $\mathrm{OM}$ & Soil organic matter content ( $\%$ by weight $)^{6}$ & $-0.314(0.670)$ & $-0.525(0.440)$ \\
\hline Awc & Soil available water capacity $(\mathrm{cm} / \mathrm{cm})^{6}$ & $8.968(0.055)$ & $1.739(0.797)$ \\
\hline Clay & Soil clay content ( $\%$ of material less than $2 \mathrm{~mm})^{6}$ & $0.036(0.109)$ & $-0.033(0.166)$ \\
\hline $\mathrm{K}$ & Universal soil loss factor $(\mathrm{k})^{6}$ & $5.653(0.017)$ & $-1.613(0.605)$ \\
\hline Drain & Soil drainage 6 & $-0.024(0.935)$ & $0.131(0.832)$ \\
\hline Slope & Soil surface slope $(\%)^{6}$ & $-0.019(0.687)$ & $-0.054(0.502)$ \\
\hline LL & Soil liquid limit (\% moisture by weight $)^{6}$ & $0.043(0.057)$ & $-0.050(0.095)$ \\
\hline Hydric & Occurrence of hydric soils ${ }^{6}$ & $-1.804(0.422)$ & $3.418(0.440)$ \\
\hline Hydro & Soil hydrologic characteristics ${ }^{6}$ & $-0.134(0.749)$ & $-0.455(0.171)$ \\
\hline Flood & Annual flood frequency of soil ${ }^{6}$ & $0.638(0.056)$ & $-0.478(0.609)$ \\
\hline Uzclay & $\begin{array}{l}\text { Average clay content of unsaturated } \\
\text { zone in sector }(\%)^{2}\end{array}$ & $0.015(0.083)$ & $-0.005(0.635)$ \\
\hline Uzsand & $\begin{array}{l}\text { Average sand content of unsaturated } \\
\text { zone in sector }(\%)^{2}\end{array}$ & $-0.038(0.033)$ & $-0.012(0.891)$ \\
\hline Dtw & Depth to regional water table $(\mathrm{m})^{2}$ & $3.94 \times 10^{-4}(0.892)$ & $-0.007(0.006)$ \\
\hline Sathik & Aquifer saturated thickness $(\mathrm{m})^{2}$ & $-2.00 \times 10^{-5}(0.986)$ & $0.002(0.427)$ \\
\hline \multicolumn{4}{|c|}{$\begin{array}{l}\text { Note: Bold values selected for initial multivariate logistic regression analysis. } \\
{ }^{1} \text { Qi et al. (2002). } \\
\text { 2Qi and Gurdak (2006). } \\
\text { }{ }^{3} \text { Ruddy et al. (2006). } \\
{ }^{4} \text { Solley et al. (1998). } \\
\text { Thaylor et al. (1997). } \\
6 \\
{ }^{2} \text { U.S. Department of Agriculture (1991). }\end{array}$} \\
\hline
\end{tabular}


several preliminary multivariate models with various combinations of explanatory variables were constructed and evaluated. Using a randomly selected subset of wells ( $n=232$ ), model calibration was evaluated using the degree of correspondence between the predicted probabilities of nitrate exceeding the threshold and the actual nitrate concentrations exceeding the threshold (Hosmer and Lemeshow 2000). The Hosmer-Lemeshow (HL) goodness-of-fit test statistic was used to evaluate the model calibration. For the HL test, the data were grouped into typically 10 deciles of risk or bins, with each bin containing approximately $10 \%$ of the total number of observations. The null hypothesis of the HL test is that the model fits the data; therefore, a higher HL $p$ value indicates a well-calibrated model (Hosmer and Lemeshow 2000). The models that best predicted the occurrence of nitrate concentrations greater than $4 \mathrm{mg} / \mathrm{L}$ in recently recharged ground water were selected on the basis of statistical significance (LLR $p$ value), model fit (partial likelihood ratio, $\mathrm{PC}$, and sensitivity), and predictive ability (Gurdak and Qi 2006). A randomly selected independent set of nitrate concentration data from wells $(n=104)$ that intercept recently recharged ground water was used for model validation to evaluate predictive ability. Using the subset of validation wells that sample recently recharged ground water, predicted probabilities were calculated with the final models and compared to observed detections of nitrate exceeding $4 \mathrm{mg} / \mathrm{L}$. Nitrate concentrations from the validation wells have a similar range as the wells used for model development and calibration and were converted to binary classification of "zero" for nitrate concentration less than $4 \mathrm{mg} / \mathrm{L}$ and "one" for nitrate concentrations equaling or exceeding $4 \mathrm{mg} / \mathrm{L}$. This binary conversion allowed for the percentage of observed detections to be calculated and compared to the average predicted probabilities within each $10 \%$ decile.

Coefficients of the explanatory variables from the final multivariate models were entered into the GIS, and a vulnerability map was created through gridded $(80 \mathrm{~m})$ GIS map-algebra techniques (Qi and Gurdak 2004, 2006). The vulnerability model and map express the predicted probability of detecting nitrate concentrations greater than $4 \mathrm{mg} / \mathrm{L}$ in recently recharged (less than 50 years) ground water of the High Plains Aquifer.

The following novel methodology produces corresponding uncertainty estimates and maps for each vulnerability model. LHS was used to develop the uncertainty prediction intervals, which defines the error range surrounding the estimates of predicted probability of ground water vulnerability to nitrate concentrations greater than $4 \mathrm{mg} / \mathrm{L}$ in recently recharged ground water within each 80 -m GIS grid cell. The $90 \%$ uncertainty prediction interval range is commonly reported, defined by the difference between the 5th and 95th percentile of the output probability distribution, and represents the likelihood that the true predicted probability of ground water vulnerability to nitrate greater than $4 \mathrm{mg} / \mathrm{L}$ is within that uncertainty prediction interval. Because the input errors, and thus the propagated model output uncertainty, are spatially variable (Phillips and Marks 1996), the uncertainty was calculated at each GIS grid cell, and the $95 \%$ uncertainty prediction intervals were presented as uncertainty maps to accompany the final vulnerability map of the High Plains Aquifer.

Uncertainty was estimated at monitoring wells and at each GIS grid cell of the study area during GIS mapalgebra calculations of probability by using the predicted probability as input for the risk-analysis program @RISK (Palisade Corporation 2002). Due to the excessively large number of $80-\mathrm{m}$ GIS grid cells $\left(n=70.4\left[10^{6}\right]\right)$ within the study area $\left(450,658 \mathrm{~km}^{2}\right)$, additional steps were taken to reduce computational runtimes; thus, GIS data resolution was decreased from 80-m (finest resolution explanatory variable in the vulnerability models) to 500-m (coarsest resolution explanatory variable in the vulnerability model) grid spacing (Qi and Gurdak 2006). Results of a Wilcoxon rank-sum test indicated that the change in resolution from $80-\mathrm{m}$ to $500-\mathrm{m}$ grid spacing did not significantly $(p>0.05)$ change the data representing each explanatory variable. Within this lower-resolution grid, LHS was considerably more efficient than the traditional MC sampling. The stratified sampling approach of LHS allowed faster convergence on the input probability distribution with fewer iterations than MC sampling. For each model simulation, 1000 LHS iterations were run. As suggested by Phillips and Marks (1996), all input probability distributions were assumed normal; each distribution mean was assigned as the estimated logistic regression coefficient or explanatory variable for that GIS grid cell. The estimation variance of the input probability distributions was defined by a conservative range of errors for each explanatory variable and by the Wald $95 \%$ confidence intervals for logistic regression model coefficients, summarized in Table 2. The Wald $95 \%$ confidence interval was calculated using the maximum likelihood estimate and the standard error estimate of the logistic regression model coefficients (Hosmer and Lemeshow 2000).

Measures of errors are typically not available for spatial databases; however, reasonable estimates of errors were obtained for the explanatory variables that were included in the vulnerability models selected as having the most statistical significance and best model fit and predictive ability. The errors for these explanatory variables ranged from $10 \%$ to $28 \%$ (Table 2) and were obtained from various sources. Explanatory variable error equal to $20 \%$ was used for both nonirrigated and irrigated agricultural land, based on Qi et al. (2002) use of satellite imagery from Landsat Thematic Mapper (nominal date 1992) and raw National Land Cover Data satellite data to classify irrigated and nonirrigated land. Qi et al. (2002) used ground reference information from $2500 \mathrm{~km}^{2}$ for comparison against the classified irrigated land data and reported an approximate $80 \%$ correct classification and $20 \%$ error estimate. Gurdak and Qi (2006) created unsaturated zone lithology GIS data sets by interpolating 56,000 lithologic logs from wells across the High Plains using ordinary kriging. Explanatory variable error for the unsaturated zone lithology was estimated at $28 \%$, based on the average root mean squared prediction error from crossvalidation during ordinary kriging. Explanatory variable error of $10 \%$ for depth to water was estimated from McGuire et al. (2003) use of ordinary kriging (average 


\begin{tabular}{|c|c|c|c|c|c|}
\hline \multicolumn{6}{|c|}{$\begin{array}{c}\text { Table } 2 \\
\text { Wald 95\% Confidence Intervals for Logistic Regression Constants and Estimated Explanatory } \\
\text { Variable Errors Used during Uncertainty Analysis }\end{array}$} \\
\hline \multirow[b]{2}{*}{ Explanatory Variables } & \multirow[b]{2}{*}{ Model Constant } & \multirow[b]{2}{*}{ Coefficient } & \multicolumn{2}{|c|}{ Wald $95 \%$ Confidence Interval } & \multirow[b]{2}{*}{ Error $(\%)$} \\
\hline & & & Lower & Upper & \\
\hline NHP model & -0.374 & & -1.477 & 0.729 & \\
\hline Nonirrigated agricultural land (\%) & & 0.023 & 0.009 & 0.036 & 20 \\
\hline Irrigated agricultural land (\%) & & 0.017 & 0.004 & 0.030 & 20 \\
\hline Soil organic matter (\% by weight) & & -1.487 & -3.148 & 0.173 & 20 \\
\hline CHP and SHP model & 1.158 & & -0.632 & 2.948 & \\
\hline Depth to regional water table (m) & & -0.010 & -0.017 & -0.004 & 10 \\
\hline Nonirrigated agricultural land (\%) & & 0.013 & 0.0004 & 0.026 & 20 \\
\hline Irrigated agricultural land $(\%)$ & & 0.011 & -0.003 & 0.026 & 20 \\
\hline Average clay content, unsaturated zone (\%) & & -0.019 & -0.043 & 0.005 & 28 \\
\hline
\end{tabular}

root mean squared prediction error from cross-validation) to interpolate between ground water monitoring wells to create a GIS data set of depth to water. A conservative error estimate for soil organic matter was arbitrarily selected as $20 \%$ because measures of uncertainty are not available for STATSGO data (U.S. Department of Agriculture 1991). The explanatory variable errors largely represent measurement accuracy within the GIS data sets.

A method originally presented by van Horssen et al. (2002) to evaluate spatial interpolation during ordinary block kriging was modified to evaluate uncertainty contributions from model and data error sources by comparing the relative variance contributions due to the regression $\left(\mathrm{RVC}_{r}\right)$ and explanatory variables $\left(\mathrm{RVC}_{e}\right)$. For the predicted probability at any given monitoring well or GIS grid cell, represented as $P$, the total prediction variance, $\sigma^{2}(P)$, is equal to the sum of the variance as a result of uncertainty in the regression coefficient, $\sigma_{r}^{2}(P)$, and variance as a result of uncertainty in explanatory variables, $\sigma_{e}^{2}(P)$. The general decomposition of the total prediction variance is as follows:

$$
\sigma^{2}(P)=\sigma_{r}^{2}(P)+\sigma_{e}^{2}(P)+2 \times \operatorname{Cov}\left[\sigma_{r}^{2}(P), \sigma_{e}^{2}(P)\right]
$$

where $2 \times \operatorname{Cov}\left[\sigma_{r}^{2}(P), \sigma_{e}^{2}(P)\right]$ is twice the covariance of each pair of terms formed from the components of the sum (Hosmer and Lemeshow 2000). Because the calculated covariance of each pair of terms is negligible (1 to 2 orders of magnitude less than uncertainty components), it is reasonable to assume independence between the two variance components. Therefore, the relative variance contribution due to regression $\left(\mathrm{RVC}_{r}\right)$ is calculated as follows:

$$
\mathrm{RVC}_{r}=\frac{\sigma_{r}^{2}(P)}{\sigma^{2}(P)} \times 100 \%
$$

and the relative variance contribution due to explanatory variables $\left(\mathrm{RVC}_{e}\right)$ is calculated as follows:

$$
\mathrm{RVC}_{e}=\frac{\sigma_{e}^{2}(P)}{\sigma^{2}(P)} \times 100 \%
$$

If uncertainty due to regression coefficients and explanatory variables contributes equally, the $\mathrm{RVC}_{r}$ will equal the $\mathrm{RVC}_{e}$. $\mathrm{RVC}_{r}$ values greater than the $\mathrm{RVC}_{e}$ values indicate locations of the aquifer where uncertainty due to regression coefficients dominates the total uncertainty. This result would indicate the need for additional monitoring wells to better characterize the variability of nitrate concentration and corresponding explanatory variables. $\mathrm{RVC}_{r}$ values lower than the $\mathrm{RVC}_{e}$ values indicate locations of the aquifer where uncertainty due to errors in explanatory variables dominates the total uncertainty. Therefore, these locations of the aquifer represent where improved measurement precision of GIS-based explanatory variables are needed to reduce $\mathrm{RVC}_{e}$ and thus improved vulnerability prediction uncertainty.

\section{Results}

\section{Vulnerability Model and Map Development}

Using univariate and multivariate logistic regression analysis, models were developed that represent the vulnerability of recently recharged ground water in the High Plains aquifer by using 336 wells, which were previously identified by Gurdak and Qi (2006) as intercepting ground water recharged during the past 50 years. The spatial distribution and nitrate concentrations at these wells are displayed in Figure 1. A summary of nitrate concentrations used for model calibration and validation is presented in Table 3. Approximately $48 \%$ of the wells were identified as having nitrate concentrations that exceed the relative background concentration of $4 \mathrm{mg} / \mathrm{L}$ (as $\mathrm{N}$ ).

Univariate relations between nitrate concentration greater than or equal to $4 \mathrm{mg} / \mathrm{L}$ and explanatory variables were evaluated and are summarized in Table 1. The logistic regression coefficients listed in Table 1 indicate the nature of the univariate relation: coefficient values greater than zero indicate positive relations, and coefficient values less than zero indicate inverse relations with nitrate greater than or equal to $4 \mathrm{mg} / \mathrm{L}$. An alpha level of 0.2 was chosen as the inclusion criterion for selecting explanatory variables into the multivariate analysis rather than the more traditional alpha level of 0.10 . Hosmer and Lemeshow (2000) suggest that an alpha level of 0.10 has failed to identify variables known to be important during 
Table 3

Summary of Nitrate Concentration Data Used in the Analysis and Number of Exceedances of the Relative Background Concentration of $4 \mathrm{mg} / \mathrm{L}$ (as N)

\begin{tabular}{|lccccc|}
\hline & $\begin{array}{c}\text { Number of } \\
\text { Analyses/Number } \\
\text { of Wells }\end{array}$ & $\begin{array}{c}\text { Number of Analyses } \\
\text { more than } \mathbf{4}(\mathbf{m g} / \mathbf{L}) \mathbf{N}\end{array}$ & Minimum & Median & Maximum \\
\cline { 4 - 6 } & $336 / 336$ & 162 & 0.02 & 3.82 & 31 \\
All data & $192 / 192$ & 96 & 0.02 & 4.00 & 31 \\
NHP & $91 / 91$ & 39 & 0.02 & 3.66 & 27 \\
CHP & $53 / 53$ & 27 & 0.21 & 4.03 & 22 \\
SHP & $232 / 232$ & 108 & 0.02 & 3.63 & 29 \\
Model calibration subset & $104 / 104$ & 54 & 0.02 & 4.23 & 31 \\
Model validation subset & & & & & \\
\hline
\end{tabular}

some multiple logistic regression analyses. Twenty-one of the 31 explanatory variables initially were carried forward for multivariate analyses. However, all explanatory variables were evaluated later using the partial likelihood ratio during multivariate analyses. The variable selection for multivariate model development required too many iterative steps to list. Using this stepwise selection process, many multivariate models that represented different spatial extents of the study area were tested for statistical significance, model fit, and predictive ability. Spatial extents tested included the entire High Plains aquifer, each subregion (NHP, CHP, and SHP), and various combinations of the subregions.

Two final multivariate models were selected with the best statistical significance, model fit, and predictive ability, and represent the NHP model and the combined CHP and SHP models. The NHP model is expressed as follows:

$$
P_{\mathrm{NHP}}=\left(\frac{\mathrm{e}^{\left[\begin{array}{c}
-0.374+(0.023 \times \text { NonIrrag }) \\
+(0.017 \times \text { Irrag })+(-1.487 \times \mathrm{OM})
\end{array}\right]}}{1+\mathrm{e}^{\left[\begin{array}{c}
-0.374+(0.023 \times \text { NonIrrag }) \\
+(0.017 \times \text { Irrag })+(-1.487 \times \mathrm{OM})
\end{array}\right]}}\right) \times 100
$$

where $P_{\mathrm{NHP}}$ is the predicted probability of detecting nitrate greater than $4 \mathrm{mg} / \mathrm{L}$ in recently recharged ground water of the NHP aquifer, NonIrrag is the percentage of nonirrigated agricultural land in the contributing area, Irrag is the percentage of irrigated agricultural land in the contributing area, and OM is organic material in the soil. The CHP and SHP model is expressed as follows:

$$
\begin{aligned}
& P_{\mathrm{CHP}} \text { and SHP } \\
& =\left(\frac{\mathrm{e}^{\left[\begin{array}{c}
1.158+(-0.010 \times \mathrm{DTW})+(0.013 \times \text { NonIrrag }) \\
+(0.011 \times \mathrm{Irrag})+(-0.019 \times \text { Uzclay })
\end{array}\right]}}{1+\mathrm{e}^{\left[\begin{array}{c}
1.158+(-0.010 \times \mathrm{DTW})+(0.013 \times \text { NonIrrag }) \\
+(0.011 \times \mathrm{Irrag})+(-0.019 \times \text { Uzclay })
\end{array}\right]}}\right) \times 100
\end{aligned}
$$

where $P_{\mathrm{CHP}}$ and SHP is the predicted probability of detecting nitrate greater than $4 \mathrm{mg} / \mathrm{L}$ in recently recharged ground water of the CHP and SHP aquifer, DTW is depth to regional water table, NonIrrag and Irrag are defined previously, and Uzclay is percent clay in the unsaturated zone. The LLR and $p$ values for the NHP model (LLR = 13.9, $p=0.003$ ) and CHP and SHP model (LLR $=16.2$, $p=0.003$ ) indicate high statistical significance (Table 4). Model fit was good, indicated by reasonable PC (NHP model $=65.8 \%$, CHP and SHP models $=70.4 \%)$ and sensitivity (NHP model $=72.4 \%$, CHP and SHP models $=$ $58.0 \%$ ) (Table 4). The overall model fit was excellent (HL goodness-of-fit $p$ value: NHP model $=0.989$, CHP and SHP models $=0.959)$ (Table 4). Linear regression comparisons of the percentage of observed detections of nitrate concentrations exceeding $4 \mathrm{mg} / \mathrm{L}$ and the average predicted probabilities for each of 10 deciles calculated for the NHP (Equation 7) and the CHP and SHP models (Equation 8) are shown (Figure 2). The percentage of observed detections of nitrate concentrations exceeding $4 \mathrm{mg} / \mathrm{L}$ was converted to binary classification of "zero" for nitrate concentrations less than $4 \mathrm{mg} / \mathrm{L}$ and "one" for nitrate concentrations equaling or exceeding $4 \mathrm{mg} / \mathrm{L}$ for each of the 10 deciles or bins, which contain approximately $10 \%$ of the total number of observations. This binary conversion, ranking, and grouping of data into deciles allowed for the direct comparison of the percentage of observed detections to predicted probabilities (Rupert 2003; Gurdak and Qi 2006).

The predictive models were validated using a randomly selected subset of wells that intercept recently recharged ground water. The combined validation results for both models show a good predictive ability, with an $r^{2}=0.834$ and negligible systematic bias (Figure 3).

A vulnerability map representing the predicted occurrence probability of recently recharged ground water of the High Plains aquifer having nitrate greater than $4 \mathrm{mg} / \mathrm{L}$ is shown in Figure 4. The probabilities were calculated at each grid cell in the study area through Equations 7 and 8.

\section{Vulnerability Prediction Uncertainty}

Simulation results from LHS of the input probability distributions used in the logistic regression model identified propagation of input errors through the model calculations. This error propagation resulted in a substantial prediction uncertainty for the calculated predicted probabilities from Equations 7 and 8. Uncertainty predictions are expressed as an output probability distribution and show the relative likelihood of predicted occurrence of elevated nitrate. The median value (50th percentile, Figure 5) of the output probability distribution represents the assumption of no input errors during calculations (Equations 7 and 8) of ground water vulnerability. 


\begin{tabular}{|c|c|c|c|c|c|c|c|c|}
\hline \multicolumn{9}{|c|}{$\begin{array}{c}\text { Table } 4 \\
\text { Logistic Regression Analysis Results, Listing Logistic Regression Coefficients, } \\
p \text { Values, and Model Fit Statistics }\end{array}$} \\
\hline \multirow[b]{2}{*}{ Explanatory Variables } & \multirow[b]{2}{*}{ Range } & \multirow[b]{2}{*}{ Median } & \multicolumn{6}{|c|}{ Model Fit } \\
\hline & & & $\underset{\text { ( } p \text { value })}{\text { LLR }}$ & $\begin{array}{l}\text { Coefficient } \\
(p \text { value })\end{array}$ & $\begin{array}{c}\text { HL } \\
(p \text { value })\end{array}$ & $r^{2}$ & $\mathrm{PC}(\%)$ & Sensitivity (\%) \\
\hline NHP & & & $13.9(0.003)$ & & 0.989 & 0.910 & 65.8 & 72.4 \\
\hline $\begin{array}{l}\text { Nonirrigated agricultural } \\
\text { land (NonIrrag) }(\%)\end{array}$ & $0-100$ & 25.3 & & $0.023(0.001)$ & & & & \\
\hline $\begin{array}{l}\text { Irrigated agricultural } \\
\text { land (Irrag) }(\%)\end{array}$ & $0-100$ & 7.78 & & $0.017(0.009)$ & & & & \\
\hline $\begin{array}{l}\text { Soil organic matter }(\mathrm{OM}) \\
\quad(\% \text { by weight })\end{array}$ & $0.27-1.69$ & 0.60 & & $-1.487(0.079)$ & & & & \\
\hline CHP and SHP & & & $16.2(0.003)$ & & 0.959 & 0.891 & 70.4 & 58.0 \\
\hline $\begin{array}{l}\text { Depth to regional water } \\
\text { table (DTW) }(\mathrm{m})\end{array}$ & $2.27-96.3$ & 40.8 & & $-0.010(0.002)$ & & & & \\
\hline $\begin{array}{l}\text { Nonirrigated agricultural } \\
\text { land (NonIrrag) }(\%)\end{array}$ & $0-100$ & 35.0 & & $0.013(0.043)$ & & & & \\
\hline $\begin{array}{l}\text { Irrigated agricultural } \\
\text { land (Irrag) }(\%)\end{array}$ & $0-100$ & 6.96 & & $0.011(0.122)$ & & & & \\
\hline $\begin{array}{l}\text { Average clay content of } \\
\text { unsaturated zone } \\
\text { (Uzclay) }(\%)\end{array}$ & $17.1-86.3$ & 50.3 & & $-0.019(0.122)$ & & & & \\
\hline
\end{tabular}

Seven representative percentiles (5th, 25th, 40th, 50th, 60th, 75th, and 95th) were selected from the output probability distribution at each calibration and validation monitoring well location for both models (Equations 7 and 8) to evaluate the effect of input errors on prediction uncertainty at the well locations (Figure 5). The larger spread of the output probability distribution for the wells used in the CHP and SHP model compared to the wells used in the NHP model indicates that the overall uncertainty is smaller for predictions of vulnerability in the NHP than in the CHP and SHP subregions. This may be attributed to the additional explanatory variable (Uzclay) in the CHP and SHP model that has a relatively high error percentage. A visual comparison of the output probability distributions for both vulnerability models in Figure 5 shows a lack of symmetry, or skewness, in the uncertainty estimates across the range of predicted ground water vulnerability. The uncertainty surrounding the NHP model is positively skewed, meaning the uncertainty is larger at predicted probabilities greater than 50 than at predicted probabilities less than 50. Conversely, uncertainty surrounding CHP and SHP model predictions is slightly negatively skewed, revealing the prediction uncertainty to be slightly larger at predicted probabilities less than 50 than for predicted probabilities greater than 50 .

To investigate the spatial variability of uncertainty surrounding ground water vulnerability predictions, the prediction interval was calculated at each GIS grid cell within the High Plains aquifer and is shown as the prediction interval map (Figure 6). The absolute uncertainty surrounding ground water vulnerability predictions tends to be larger within the CHP and SHP than in the NHP
(Figure 6). However, the intramodel variance of prediction intervals tends to be larger for the NHP model than the CHP and SHP model (Figure 6). The north-central portion of the NHP subregion is dominated by rolling hills and little agriculture, which was predicted with great confidence as having a low probability of elevated nitrate in ground water, despite few wells in this area. Conversely, the central portion of the CHP subregion was predicted as having a low probability of elevated nitrate, yet with a larger uncertainty. The vulnerability map (Figure 4) used in concert with the prediction interval map (Figure 6) reveals that predicted ground water vulnerability of the High Plains aquifer varies spatially, as does its associated prediction uncertainty.

\section{Uncertainty Contributions}

Comparison of the relative variance contributions due to regression $\left(\mathrm{RVC}_{r}\right)$ to the relative variance contributions due to explanatory variables $\left(\mathrm{RVC}_{e}\right)$ reveals that relative input errors caused by the model contribute more to the overall prediction uncertainty for the entire domain (Figure 7). However, if the relative variance contributions are calculated separately for the NHP model and the CHP and SHP model (Figure 7), spatial patterns of uncertainty contributions emerge. Using the Wilcoxon rank-sum test, the $\mathrm{RVC}_{r}$ was significantly $(p<0.001)$ greater than $\mathrm{RVC}_{e}$ for wells of the CHP and SHP model, indicating that spatial patterns of prediction uncertainty across the CHP and SHP subregions are largely due to a lack of monitoring wells needed to most adequately describe the spatial variability of nitrate concentrations in recently recharged ground water. A systematic, and possible cost-effective, strategy for future ground water vulnerability assessment 

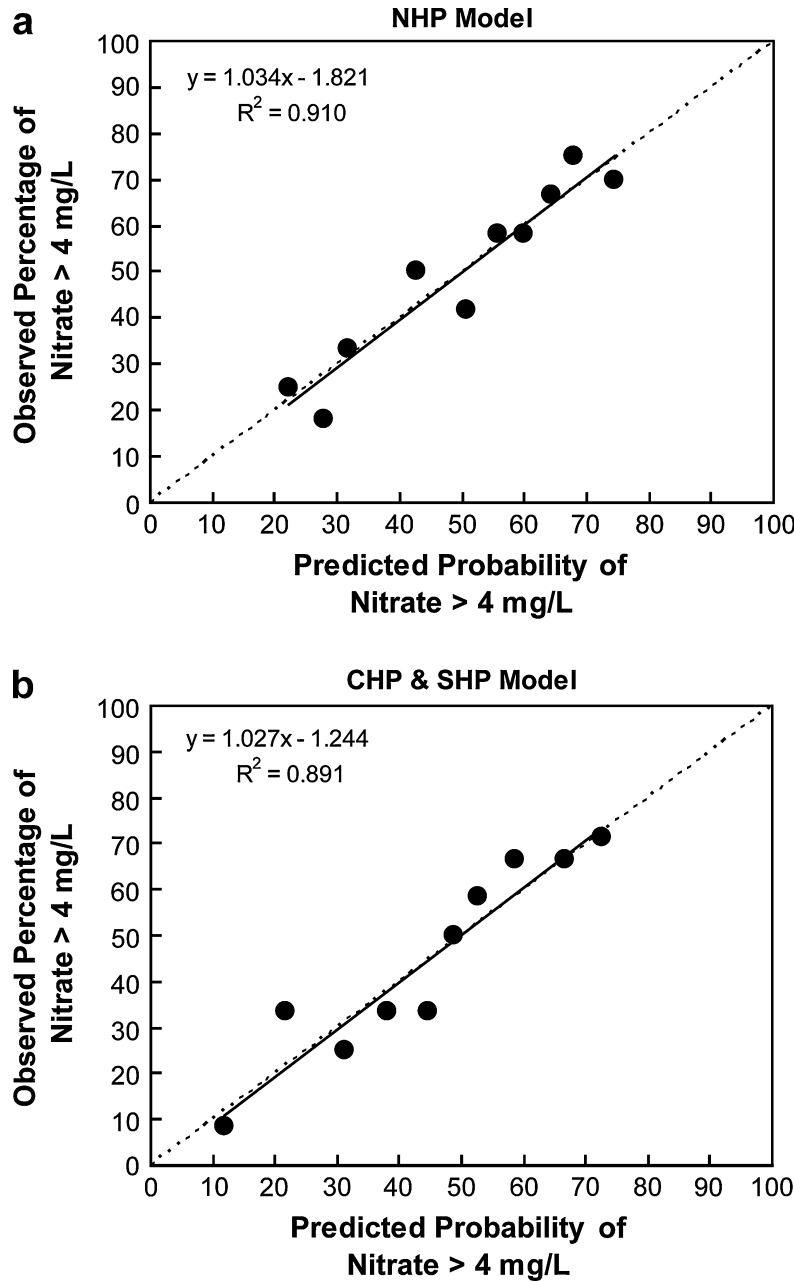

Figure 2. Percentage of observed nitrate detections greater than the relative background concentration $(4 \mathrm{mg} / \mathrm{L})$ and the average predicted probability of detecting nitrate greater than $4 \mathrm{mg} / \mathrm{L}$ (calibration date) for deciles of the (a) NHP model and (b) CHP and SHP model. The dashed line represents the $1: 1$ ratio.

of the High Plains aquifer to reduce prediction uncertainty across the CHP and SHP subregions may be to add monitoring wells specifically in areas with the widest prediction intervals, identified in Figure 6, followed by the addition of monitoring wells in areas of the CHP and SHP with smaller prediction intervals. Conversely, the $\mathrm{RVC}_{e}$ of the NHP model is significantly $(p<0.001)$ larger than $\mathrm{RVC}_{r}$, indicating that errors associated with GIS explanatory variables are greater than errors caused by a lack of spatial distribution of monitoring wells to adequately describe spatial variability in nitrate concentrations. In the NHP, a systematic, and possibly cost-effective, strategy to reduce uncertainty would entail the use of GIS explanatory variables with smaller error, particularly in the northeastern area (Figure 6).

\section{Discussion}

As shown by the results of the High Plains aquifer vulnerability assessment, input error propagation can lead to substantial prediction uncertainty of logistic regression

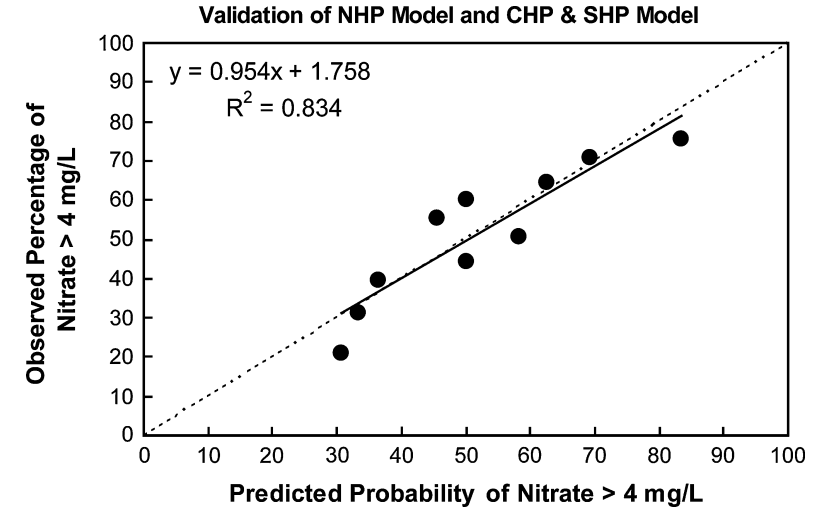

Figure 3. Percentage of observed nitrate detections greater than the relative background concentration $(4 \mathrm{mg} / \mathrm{L})$ and the average predicted probability of detecting nitrate greater than $4 \mathrm{mg} / \mathrm{L}$ (validation date) for deciles. The dashed line represents the 1:1 ratio.

ground water vulnerability models coupled with GIS. The proposed LHS methodology is beneficial because it identifies potential sources of uncertainty in ground water vulnerability predictions and provides a quantitative means for evaluating and managing the various sources of uncertainty toward improved vulnerability predictions.

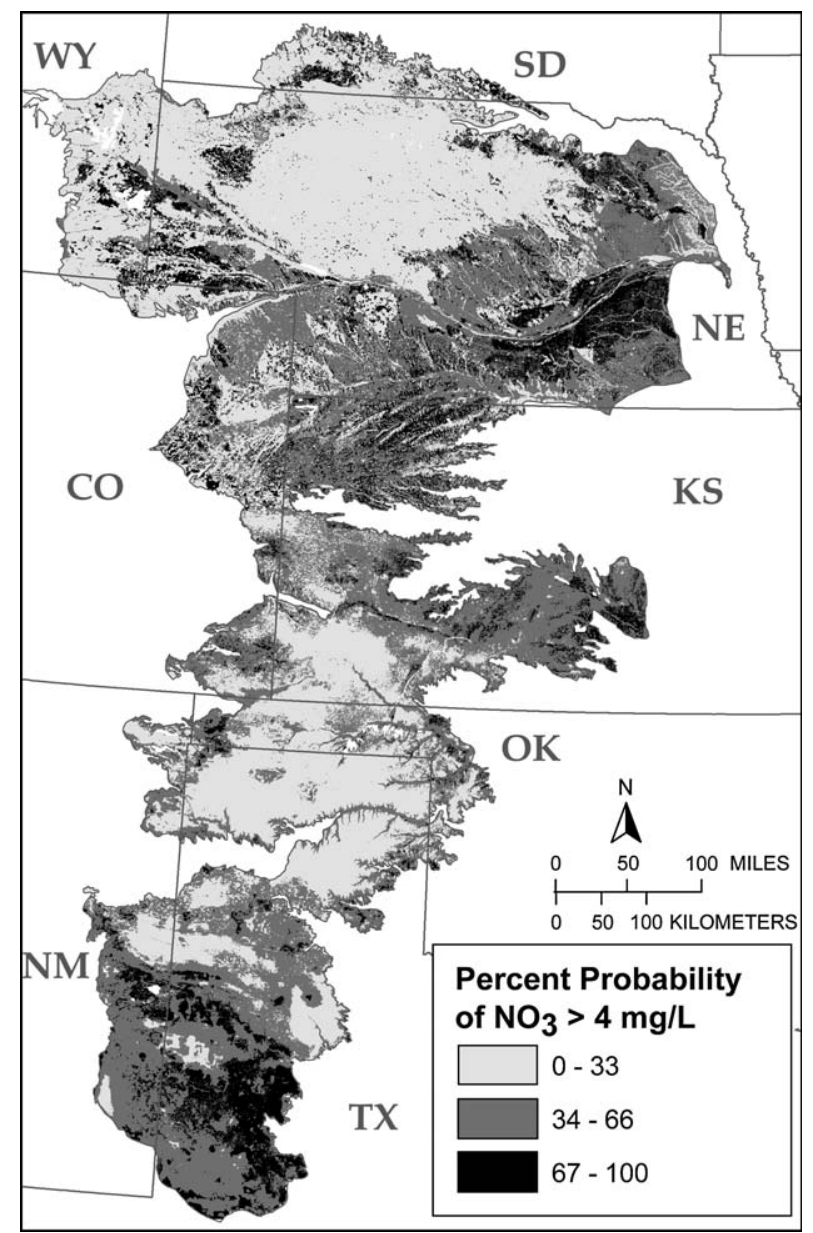

Figure 4. Spatial distribution of the probability of detecting nitrate greater than $4 \mathrm{mg} / \mathrm{L}$ in recently recharged ground water. 


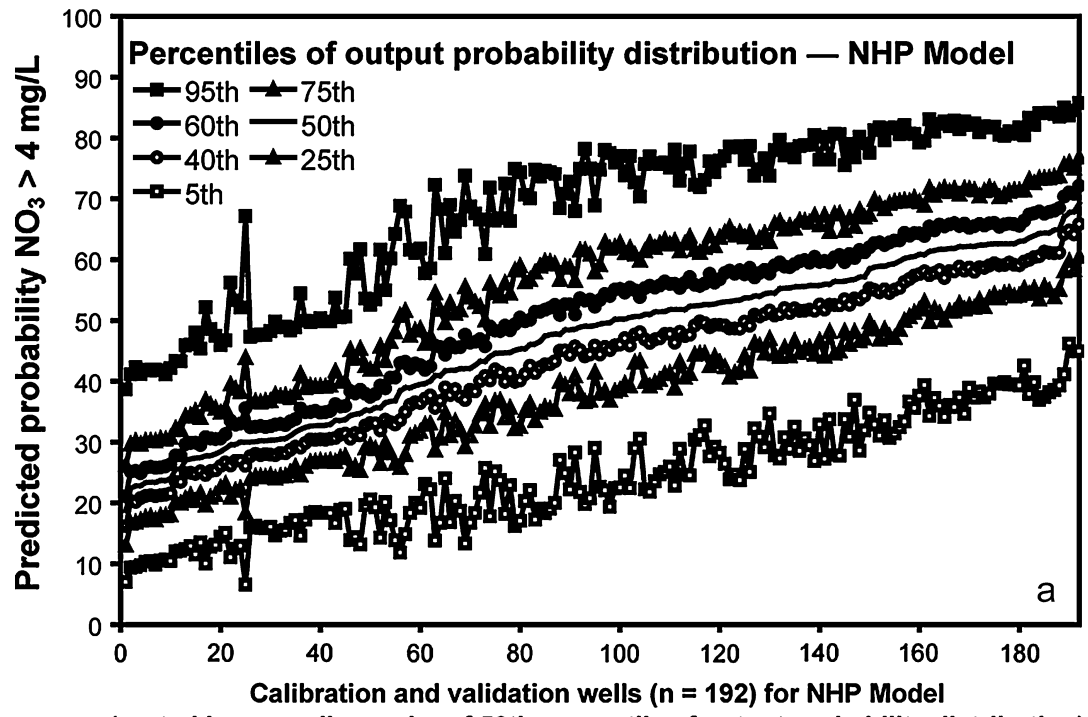

(sorted in ascending order of 50th percentile of output probability distribution)

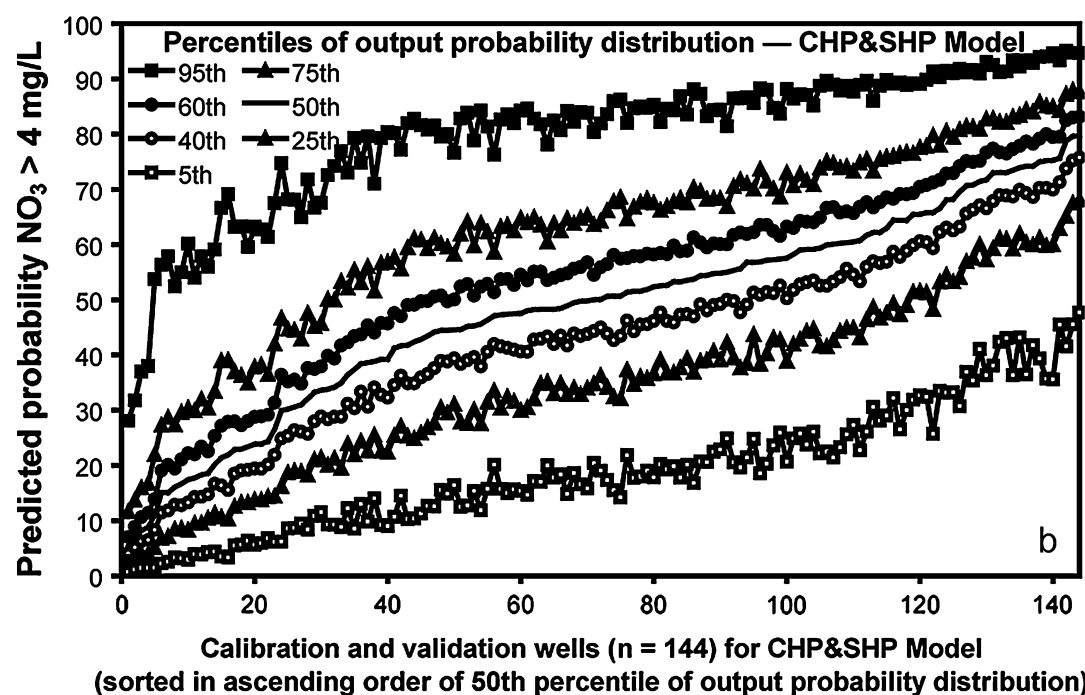

Figure 5. Selected percentiles (5th, 25th, 40th, 50th, 60th, 75th, and 95th) from the output probability distribution for predicted probabilities of monitoring wells, sorted in ascending order of the 50th percentile, for the (a) NHP model and (b) CHP and SHP model.

For example, future vulnerability assessments of the High Plains aquifer will benefit from increased spatial density of monitoring wells located within the CHP and SHP and from smaller errors in GIS-based explanatory variables within the NHP.

The practical advantages and utility of using LHS to quantify uncertainty associated with logistic regression vulnerability model predictions are numerous. The proposed method can easily be modified for application in other hydrogeological settings. The explanatory variables, and associated GIS-based errors, that control NPS contamination and constrain the ground water vulnerability model are likely to be different in other aquifers. The proposed method allows for flexibility in defining the LHS input probability distributions based on the errors of GISbased explanatory variables selected as most important to an aquifer. Ground water vulnerability prediction uncertainty presented as a probability distribution allows water resource managers to define multiple "best case" and "worse case" probable scenarios of NPS contamination, depending on any specified level of acceptable resource management or sustainability risk. For example, water resource managers who want a more conservative level of acceptable risk may choose to use a smaller prediction interval than the $90 \%$ uncertainty prediction interval used in the High Plains aquifer example. Further, spatial representations of the uncertainty as probability distributions within GIS (Figure 6) provide the necessary tools for resource managers to allocate site-specific resources to improve future assessments of NPS contamination of ground water. The use of stochastic methods to estimate ground water vulnerability is an improvement over other uncertainty estimation methods, such as those that simply assume prediction uncertainty is inversely related to the number of observations (Bekesi and McConchie 2000). LHS could also be implemented within an ordinal logistic regression model if multiple thresholds of NPS contaminants are of interest.

The proposed method of uncertainty estimation has some limitations. The commonly used approach of 


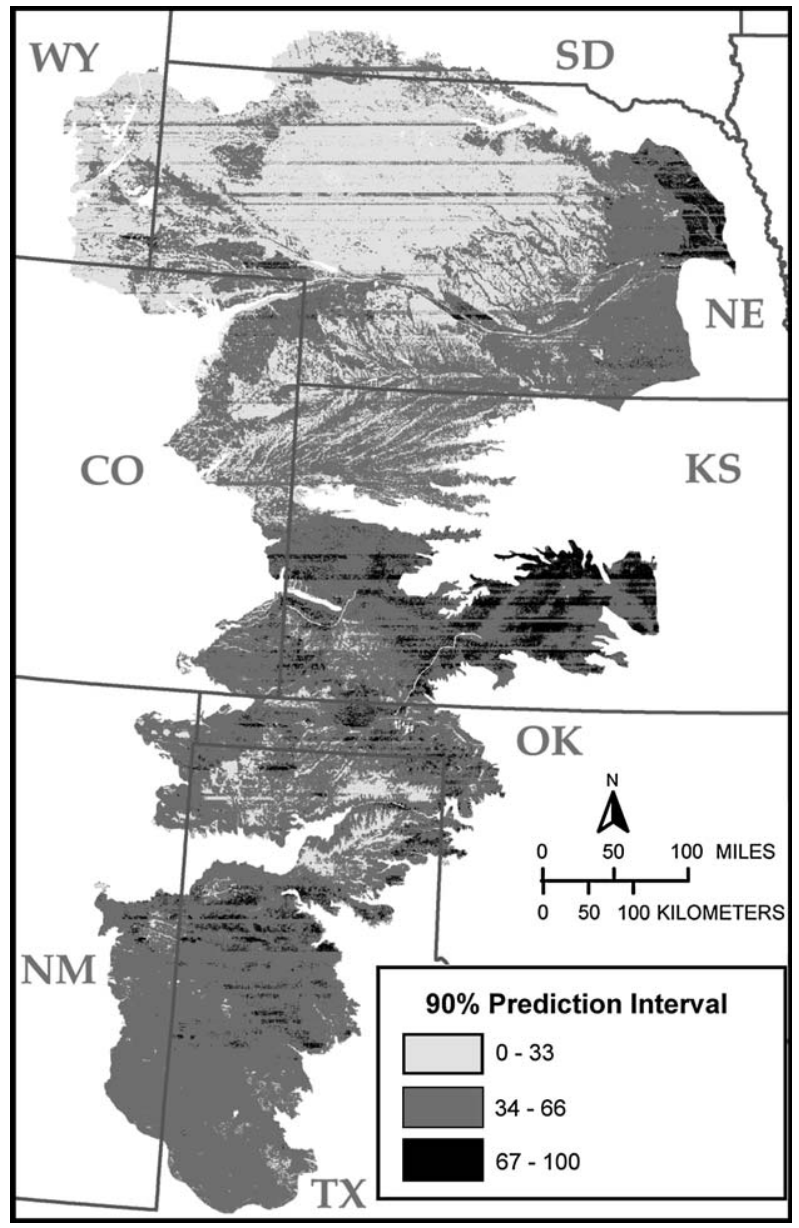

Figure 6. Spatial distribution of the $90 \%$ prediction interval for the probability of detecting nitrate greater than $4 \mathrm{mg} / \mathrm{L}$ in recently recharged ground water.

assuming normal input probability distributions was used, when in fact the true distribution shape of the input errors is never known. Additionally, the associated errors of geospatial databases are rarely reported, limiting the number of GIS-based explanatory variables that may be used in the uncertainty estimation. However, such methods

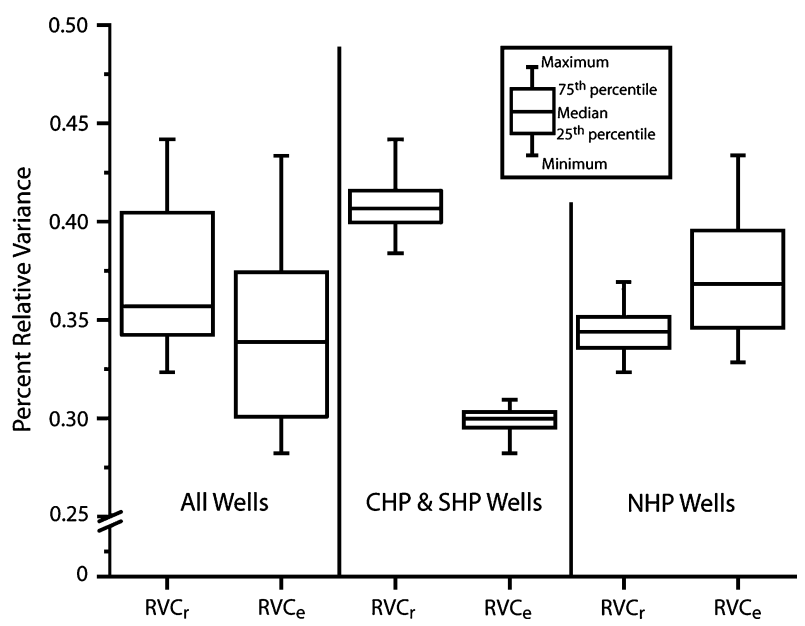

Figure 7. Comparison of $\mathrm{RVC}_{r}$ and $\mathrm{RVC}_{e}$ distributions by location. may advance the need for improved descriptions of inherent errors in geospatial data. Although the proposed methods used uncertainty estimates in the assessment after selection of explanatory variables during logistic regression model development, the authors suggest future vulnerability assessments consider the inherent uncertainty of explanatory variables during model calibration. For example, an explanatory variable deemed statistically significant during multivariate logistic regression analysis may not be a desirable explanatory variable for the final vulnerability model if the inherent error is exceptionally larger than the other statistically significant variables. Associated uncertainty of explanatory variables would therefore become additional selection criteria for inclusion in ground water vulnerability models.

The vulnerability and uncertainty maps provide tools to help resource decision makers prioritize areas for ground water quality monitoring or implement alternative management practices. These maps of the High Plains aquifer are intended for regional, subregional, or countyscale use and may have several limitations for use at the site scale or field scale. These maps are not appropriate at any scale larger than 1:250,000, as determined by the STATSGO soil data, which have the smallest scale $(1: 250,000)$ of the explanatory variables used in the final statistical models. The models and maps do not explicitly account for local point sources of nitrate or features and processes that may promote focused recharge, preferential flow, or bypass mechanisms. Additionally, the spatial distribution of wells used for model calibration was not uniform across the entire aquifer. Therefore, models and maps may not appropriately support local-scale decisions.

The probability and uncertainty maps were created using nitrate data and explanatory variables that were collected from 1990 to 2004 to illustrate spatial predictions of nitrate vulnerability. Because agricultural practices leading to nitrogen loading and mobilization have remained relatively constant during this time period, this vulnerability assessment represents the probability and associated uncertainty of detecting nitrate under current conditions. Temporal validation of these maps using data collected from previous time periods has not been evaluated. These maps were based on empirical observations at point locations from a discrete time period; therefore, forecasting of future aquifer vulnerability and uncertainty using the presented models or maps may not be appropriate and would require additional validation.

\section{Conclusions}

The proposed LHS method quantifies prediction uncertainty associated with ground water vulnerability models that use multivariate logistic regression with GIS. As illustrated from the High Plains aquifer application, the propagation of input errors through this type of ground water vulnerability model can result in substantial and spatially variable prediction uncertainty. For improved confidence in model prediction, the LHS method systematically identifies specific areas of an aquifer where additional monitoring wells or improved GIS data with lower error are needed to reduce the prediction uncertainty. 
Reducing ground water vulnerability model uncertainty will lead to improved decisions about best management practices and sustainability of ground water resources.

\section{Acknowledgments}

The authors acknowledge support for this study by the High Plains Regional Ground Water Study unit of the USGS National Water-Quality Assessment Program. We thank David Eckhardt, Michael Moran, Ken Rainwater, and an anonymous reviewer for their comments on earlier drafts of this article.

\section{References}

Bekesi, G., and J. McConchie. 2000. Empirical assessment of the influence of the unsaturated zone on aquifer vulnerability, Manawatu Region, New Zealand. Ground Water 38, no. 2: 193-199.

Bruce, B.W., M.F. Becker, L.M. Pope, and J.J. Gurdak. 2003. Ground-water quality beneath irrigated agriculture in the central High Plains aquifer, 1999-2000. USGS WaterResources Investigations Report 03-4219. Reston, Virginia: USGS.

Dennehy, K.F. 2000. High Plains regional ground-water study. USGS Fact Sheet FS-091-00. Reston, Virginia: USGS

Eckhardt, D.A.V., and P.E. Stackelberg. 1995. Relation of ground-water quality to land use on Long Island, New York. Ground Water 33, no. 6: 1019-1033.

Focazio, M.J., T.E. Reilly, M.G. Rupert, and D.R. Helsel. 2002. Assessing ground-water vulnerability to contamination: Providing scientifically defensible information for decision makers. USGS Circular 1224. Reston, Virginia: USGS.

Gottsegen, J., D. Montello, and M. Goodchild. 1999. A comprehensive model of uncertainty in spatial data. In Spatial Accuracy Assessment: Land Information Uncertainty in Natural Resources, ed. K. Lowell and A. Jaton, 175-182. Chelsea, Michigan: Ann Arbor Press.

Gurdak, J.J., and J.E. McCray. 2005. Ground-water vulnerability to pesticides: Statistical approaches. In Encyclopedia of Water, GW-451. ed. J.H. Lehr and J. Keeley, 594-599. New York: John Wiley and Sons.

Gurdak, J.J., and S.L. Qi. 2006. Vulnerability of recently recharged ground water in the High Plains aquifer to nitrate contamination. USGS Scientific Investigations Report 2006-5050. Reston, Virginia: USGS.

Helsel, D.R., and R.M. Hirsch. 1992. Statistical Methods in Water Resources. New York: Elsevier Science Publishing Company.

Hosmer, D.W., and S. Lemeshow. 2000. Applied Logistic Regression. New York: John Wiley and Sons.

Loague, K. 1991. The impact of land use on estimates of pesticide leaching potential: Assessments and uncertainties. Journal of Contaminant Hydrology 8, no. 2: 157-175.

Loague, K., R.L. Bernknopf, R.E. Green, and T.W. Giambelluca. 1996. Uncertainty of ground-water vulnerability assessment for agricultural regions in Hawaii: Review. Journal of Environmental Quality 25, no. 3: 475-490.

Luckey, R.L., E.D. Gutentag, F.J. Heimes, and J.B. Weeks. 1986. Digital simulation of ground-water flow in the High Plains aquifer in parts of Colorado, Kansas, Nebraska, New Mexico, Oklahoma, South Dakota, Texas, and Wyoming. USGS Professional Paper 1400-D. Reston, Virginia: USGS.

Magder, L.S., and J.P. Hughes. 1997. Logistic regression when the outcome is measured with uncertainty. American Journal of Epidemiology 146, no. 2: 195-203.

McGuire, V.L., M.R. Johnson, R.L. Schieffer, J.S. Stanton, S.K. Sebree, and I.M. Verstraeten. 2003. Water in storages and approaches to ground-water management, High Plains aquifer, 2000. USGS Circular 1243. Reston, Virginia: USGS.
McKay, M.D., R.J. Beckman, and W.J. Conover. 1979. A comparison of three methods for selecting values of input variables in the analysis of output from a computer code. Technometrics 21, no. 2: 239-245.

McMahon, P.B. 2001. Vertical gradients in water chemistry in the Central High Plains aquifer, southwestern Kansas and Oklahoma panhandle, 1999. USGS Water-Resources Investigations Report 01-4028. Reston, Virginia: USGS.

McMahon, P.B., K.F. Dennehy, B.W. Bruce, J.K. Böhlke, R.L. Michel, J.J. Gurdak, and D.B. Hurlbut. 2006. Storage and transit time of chemicals in thick unsaturated zones under rangeland and irrigated cropland, High Plains, United States. Water Resources Research 42, 18.

McMahon, P.B., J.K. Böhlke, and S.C. Christenson. 2004. Geochemistry, radiocarbon ages, and paleorecharge conditions along a transect in the central High Plains aquifer, southwestern Kansas, USA. Applied Geochemistry 19, no. 11: $1655-1686$

Menard, S. 2002. Applied Logistic Regression Analysis. Thousand Oaks, California: Sage Publications Inc.

Murray, K.E., and J.E. McCray. 2005. Development and application of a regional-scale pesticide transport and groundwater vulnerability model. Environmental \& Engineering Geoscience 11, no. 3: 271-284.

Nolan, B.T. 2001. Relating nitrogen sources and aquifer susceptibility to nitrate in shallow ground water of the United States. Ground Water 39, no. 2: 290-299.

Nolan, B.T., K.J. Hitt, and B.C. Ruddy. 2002. Probability of nitrate contamination of recently recharged ground waters in the conterminous United States. Environmental Science \& Technology 36, no. 10: 2138-2145.

Palisade Corporation. 2002. Guide to Using @RISK, Risk Analysis and Simulation Add-in for Microsoft Excel. Newfield, New York: Palisade Corporation.

Phillips, D.L., and D.G. Marks. 1996. Spatial uncertainty analysis: Propagation of interpolation errors in spatially distributed models. Ecological Modeling 91, no.1: 213-229.

Qi, S.L., and J.J. Gurdak. 2006. Percentage of probability of nonpoint source nitrate contamination of recently recharged ground water in the High Plains aquifer. USGS Data Series. http://water.usgs.gov/lookup/getspatial?ds192_ hp_npctprob (accessed May 19, 2006).

Qi, S.L., and J.J. Gurdak. 2004. GIS and statistical ground-water vulnerability modeling. In ESRI International User Conference Proceedings 2004. Redlands, California: ESRI

Qi, S.L., A. Konduris, D.W. Litke, and J. Dupree. 2002. Classification of irrigated land using satellite imagery, the High Plains aquifer, nominal data 1992. USGS WaterResources Investigations Report 02-4236. Reston, Virginia: USGS.

Ruddy, B.C., D.L. Lorenz, and D.K. Mueller. 2006. Countylevel estimates of nutrient inputs to the land surface of the conterminous United States, 1982-2000. U.S. Geological Survey Scientific Investigations Report 2006-5012. Reston, Virginia: USGS.

Rupert, M.G. 2003. Probability of detecting atrazine/desethylatrazine and elevated concentrations of nitrate in ground water in Colorado. USGS Water-Resources Investigations Report 02-4269. Reston, Virginia: USGS.

Rupert, M.G. 1998. Probability of detecting atrazine/desethylatrazine and elevated concentrations of nitrate $\left(\mathrm{NO}_{2}+\mathrm{NO}_{3}-\right.$ $\mathrm{N}$ ) in ground water of the Idaho part of the upper Snake River Basin. USGS Water-Resources Investigations Report 98-4203. Reston, Virginia: USGS.

SAS Institute. 1999. SAS User's Manual. Cary, North Carolina, SAS Institute Inc.

Solley, W.B., R.R. Piercem, and H.A. Perlman. 1998. Estimated use of water in the United States in 1995. U.S. Geological Survey Circular 1200. Reston, Virginia: USGS.

Squillace, P.J., and M.J. Moran. 2000. Estimating the likelihood of MTBE occurrence in drinking water supplied by groundwater sources in the Northeast and Mid-Atlantic regions of 
the United States. USGS Open-File Report 00-343. Reston, Virginia: USGS.

Taylor, G., C. Daly, W. Gibson, and J. Sibul-Weisburg. 1997. Digital and map products produced using PRISM. In 10th Conference on Applied Climatology, Reno, Nev., American Meteorological Society, 217-218. Boston, Massachusetts: Meteorological Society.

Teso, R.R., M.P. Poe, T. Younglove, and P.M. McCool. 1996. Use of logistic regression and GIS modeling to predict ground-water vulnerability to pesticides. Journal of Environmental Quality 25, no. 3: 425-432.

Tesoriero, A.J., and F.D. Voss. 1997. Predicting the probability of elevated nitrate concentrations in the Puget Sound basin: Implications for aquifer susceptibility and vulnerability. Ground Water 35, no. 6: 1029-1039.

Twarakavi, N.K.C., and J.J. Kaluarachchi. 2005. Aquifer vulnerability assessment to heavy metals using ordinal logistic regression. Ground Water 43, no. 2: 200-214.
U.S. Department of Agriculture. 1991. State Soil Geographic (STATSGO) Database. U.S. Department of Agriculture, Soil Conservation Service, Miscellaneous Publication 1492. Fort Worth, Texas: U.S. Department of Agriculture, NRCS National Cartography and GIS Center.

U.S. EPA. 2004. Current drinking water standards: Office of Water. http://www.epa.gov/safewater/mcl.html (accessed June 2004).

van Horssen, P.W., E.J. Pebesma, and P.P. Schot. 2002. Uncertainties in spatially aggregated predictions from a logistic regression model. Ecological Modelling 154, no. 1-2: 93-101.

Waterloo Hydrogeologic. 1999. Visual MODFLOW User's Manual. Waterloo, Ontario, Canada: Waterloo Hydrogeologic, Inc.

Zhang, R., J.D. Hamerlink, S.P. Gloss, and L. Munn. 1996. Determination of non-point source pollution using GIS and numerical models. Journal of Environmental Quality 25, no. 3: 411-418. 